K A N D A I

\begin{tabular}{|l|l|l|}
\hline Volume 17 & No. 1, Mei 2021 & Halaman 135-152 \\
\hline
\end{tabular}

\title{
FILOSOFI MASYARAKAT KERINCI DALAM KENDURI SKO (Philosophy of Kerinci Community in Kenduri Sko)
}

\author{
Ricky Aptifive Manik \\ Kantor Bahasa Provinsi Jambi \\ Jalan Arif Rahman Hakim No. 101 Telanaipura, Kota Jambi, Indonesia \\ Pos-el: rickymanik@gmail.com \\ (Diterima: 3 Maret 2020; Direvisi: 3 September 2020; Disetujui: 7 Mei 2021)
}

\begin{abstract}
Kenduri sko is an oral tradition of the Kerinci community which is still preserved today due to its philosophical values as the socio-cultural practice of the community. Therefore, this study aims to describe the philosophy of the Kerinci community in kenduri sko tradition. This study uses a qualitative method with data collection techniques using research instruments, namely in-depth interviews with traditional stakeholders, linguists, as well as reading relevant literature. Participant observation was conducted by using recording devices and cameras as documentation. Data of this study were analyzed using the philosophy of $A B S-S B K$. The result of this study shows that Kenduri Sko is a procession of the inauguration of traditional titles carried out at the end of harvest time. The philosophy of Kerinci community that appears in Kenduri Sko namely: 1) The religious philosophy which manifests in the form of expressions of gratitude and thanks to God for giving the harvest as sko; 2) The philosophy of humanity is implemented in gratitude to God and ancestors who have given sko ico pakai in the form of land and traditional titles, as well as how human values are practiced such as respecting, loving, cooperating, and helping others; 3) The philosophy of democracy and deliberation implemented in the granting of custom titles through the customary deliberation system; 4) The social community philosophy that manifests in the form of appreciation, respect for God and ancestors, tolerance and respect for others in deliberation, cooperation, and harmony of life in the community.
\end{abstract}

Keywords: philosophy, humanity, democracy, social, kenduri sko

\begin{abstract}
Abstrak
Kenduri Sko merupakan tradisi lisan masyarakat Kerinci yang masih dipertahankan sampai saat ini karena mengandung nilai-nilai filosofi sebagai praktik sosialkultural masyarakatnya. Oleh sebab itu, tujuan dari penelitian ini adalah mendeskripsikan filosofi masyarakat Kerinci yang terdapat di dalam tradisi kenduri sko. Penelitian ini menggunakan metode kualitatif dengan teknik pengumpulan data menggunakan instrumen penelitian, yaitu wawancara mendalam dengan pemangku adat dan ahli bahasa, serta membaca literatur yang relevan. Observasi partisipasi akan dilengkapi dengan alat rekam dan kamera sebagai dokumentasi. Selisik data menggunakan konsep falsafah ABS-SBK. Hasil selisik dari penelitian ini menunjukkan bahwa Kenduri Sko adalah prosesi pengukuhan gelar adat yang dilaksanakan pada saat habis penen. Adapun filosofi masyarakat Kerinci dalam Kenduri Sko, yaitul) filosofi keagamaan yang mewujud dalam bentuk ungkapan syukur dan terima kasih kepada Tuhan karena telah memberikan hasil panen sebagai sko; 2) filosofi kemanusiaan terimplementasi dalam ucapan syukur kepada Tuhan dan kepada leluhur yang telah memberikan sko ico pakai berupa tanah dan gelar adat, serta bagaimana nilai-nilai kemanusiaan itu dipraktikkan seperti menghargai, mengasihi, bekerja sama, dan menolong orang lain; 3) filosofi demokrasi dan musyawarah yang terimplementasi dalam pemberian gelar adat dengan sistem kerapatan; 4) filosofi sosial kemasyarakatan yang mewujud dalam bentuk penghargaan, penghormatan kepada Tuhan dan leluhur, tenggang rasa dan
\end{abstract}


menghormati orang lain dalam musyawarah, kerja sama, gotong royong, dan hidup rukun di dalam masyarakat.

Kata-kata kunci: filosofi, kemanusiaan, demokrasi, sosial, kenduri sko

DOI: 10.26499/jk.v17il.2240

How to cite: Manik, R. A. (2021). Filosofi masyarakat Kerinci dalam kenduri sko. Kandai, 17(1), 135-152 (DOI: 10.26499/jk.v17i1.2240)

\section{PENDAHULUAN}

Ada empat bentuk pusaka yang dimiliki oleh masyarakat Kerinci, yaitu harta, sko, ilmu, dan gawe kerapat atau gotong-royong. Jika harta merupakan warisan yang datang dari orang tua lakilaki, sko merupakan warisan yang diberikan atau datang dari orang tua perempuan secara turun-temurun. Pusaka ilmu didapat dari guru secara individu melalui pendidikan baik formal maupun non-formal, sedangkan gawe kerapat dimiliki sebagai pusaka melalui orang banyak. Oleh sebab itu, bagi orang Kerinci, keempat pusaka itu sudah pasti dimiliki oleh setiap orang tidak ada orang (Kerinci) yang tidak memiliki pusaka.

Pusaka sko terdiri dari dua macam, yaitu sko tanah boleh di-ico (diolah, digarap, dimanfaatkan) dan sko gelar boleh dipakai. Sko gelar dilekatkan pada saudara laki-laki dari pihak ibu atau yang disebut sebagai mamak yang mendapatkan mandat dari kaumnya.

Dalam sebuah masyarakat tradisional, warisan atau peninggalan leluhur merupakan pusaka yang sangat berharga. Oleh karena itu, pusaka tersebut dapat dianggap sebagai identitas yang penting — bahkan keramat — untuk dijaga dan dipertahankan. Cara yang biasanya dilakukan untuk menjaga pusaka oleh masyarakat tradisi itu adalah dengan melakukan upacara/ritual tradisi tersebut dalam waktu-waktu tertentu. Hal tersebut bahkan sudah menjadi cara hidup bagi masyarakat pemiliknya. Geertz (Geertz, 1983) mengatakan cara hidup menjaga pusaka adalah sebagai cara mengingatkan hubungan manusia akan keberadaannya dengan lingkungannya. Salah satunya adalah tradisi kenduri sko (KS) yang dilakukan oleh masyarakat Kerinci.

Uniknya, tradisi ini hampir dilakukan oleh seluruh desa yang ada di Kabupaten Kerinci, kecuali daerahdaerah yang mayoritas didiami oleh etnik lain. Tiap-tiap desa berbeda-beda waktu pelaksanaannya, ada yang diadakan sekali setahun dan ada yang tujuh sampai sepuluh tahun sekali (Arzam, 2016; Helida, 2016; Pranata \& Ikhsan, 2018). Hal ini menandakan bahwa bagi masyarakat Kerinci, pusaka yang diwariskan leluhur adalah identitas dan jati diri yang harus mereka hormati dan dijaga. Tradisi ini terbukti masih ada sampai saat ini dan bahkan kemungkinan kuat akan terus ada hingga anak-cucu mereka. Namun, beberapa tahun belakangan menurut Nukman (wawancara, 5 Februari 2020), tradisi KS rentan atau berpotensi dipolitisasi. Mengingat kegiatan ini merupakan pesta rakyat yang melibatkan masyarakat banyak dan pembiayaan yang cukup besar, KS dapat dijadikan ruang sosialisasi para calon kepala daerah dan pengukuhan diri pada saat masa pilkada. Secara substansi ada dua hal penting yang tidak dapat dihilangkan dari KS, yaitu penurunan benda-benda pusaka dan penobatan gelar (Helida, 2016; Pranata \& Ikhsan, 2018) Penobatan gelar ini berpotensi digunakan (dipolitisasi) dalam momentum pilkada. Namun, dalam penelitian ini penulis tidak akan membahas aspek politisasi yang terdapat dalam KS karena bukan menjadi fokus 
penelitian ini. Penulis akan berfokus pada aspek filosofi masyarakat Kerinci yang ada di dalam tradisi KS. Adapun rangkaian tradisi $\mathrm{KS}$ meliputi mulai dari rapat yang dilakukan oleh Tigo Tungku Sajarangan (tokoh adat, alim ulama, dan cerdik pandai) yang berisi tentang penentuan siapa-siapa yang akan dinobatkan sebagai pemangku adat (depati), membahas berbagai persoalan yang terjadi di tengah masyarakat, mengidentifikasi para tua-tua yang dipurnatugaskan statusnya sebagai pengurus adat, sekaligus menentukan arah/waktu yang tepat dan menunjuk kepanitiaan dalam melangsungkan KS.

Apabila di dalam masyarakat tersebut masih memiliki benda-benda pusaka, penurunan dan penyucian/pembersihan benda-benda pusaka itu menjadi hal yang mesti dilakukan di dalam KS (Sepdwiko, 2016; Zakaria, 1984). Benda pusaka ini juga menjadi alat pengukuhan bagi orang-orang yang akan dinobatkan atau diberi gelar adat. Tidak luput pula, dalam rangkaian KS tersebut, berbagai kesenian tradisi yang dimiliki masyarakat Kerinci dipertunjukkan, seperti tari asyiek, tari tauh, tari rangguk, dan lain-lain yang hampir keseluruhannya mengandung spirit nenek moyang masyarakat Kerinci. Setelah itu diakhiri dengan makan bersama (makan bajamba) seluruh masyarakat dan tamu-tamu yang datang. Keseluruhan aktivitas KS ini diikuti melibatkan seluruh masyarakat pemiliknya.

Selain sebagai ritual penobatan pemangku adat dan penurunan benda pusaka untuk dibersihkan, KS merupakan tradisi kegembiraan masyarakat selepas panen. Dengan tanahnya yang subur, mata pencarian yang bersandar pada lahan yang luasmemanen hasil bercocok tanamdimanifestasikan dalam kegembiraan bersama. Hal ini juga menandakan bahwa lahan bertani/berkebun merupakan pusaka yang mesti digarap/diolah oleh kaum secara turuntemurun. Tanah kaum yang tidak dapat diperjualbelikan kepada pihak lain.

Dua pusaka yang dimiliki oleh masyarakat Kerinci ini sudah menjadi jati diri yang tidak bisa dilepaskan dalam kehidupan mereka, yaitu pusaka yang berbentuk benda dan gelar adat, serta pusaka yang berbentuk harta warisan yang berasal dari nenek moyang. Sikap penghargaan dan ungkapan rasa syukur akan kepemilikan pusaka tersebut mereka wujudkan dalam bentuk tradisi KS yang sampai saat ini masih dipertahankan. Pertanyaan yang kemudian muncul adalah mengapa KS begitu penting bagi masyarakat Kerinci untuk dilakukan? Ini satu pertanyaan pokok yang dapat menjawab berbagai pertanyaan-pertanyaan terkait dengan sikap, perilaku, dan pola hidup yang terintegrasi di dalam kehidupan masyarakat Kerinci. Oleh sebab itu, penulis mengasumsikan bahwa di dalam tradisi KS tersebut terkandung filosofi kehidupan masyarakat Kerinci.

Asumsi ini semakin dikuatkan dengan falsafah orang Kerinci sendiri yang terdapat dalam Tambo Sakti Alam Kerinci (Zakaria, 1984), yaitu Adat Basandi Syara, Syara Basandi Kitabullah (ABS-SBK). Adat yang berasal dari nenek moyang berlandaskan pada agama dan agama berlandaskan pada kitab suci Al-Quran. Semua itu menjadi satu-kesatuan yang tidak dapat dilepaskan di dalam cara kehidupan orang Kerinci. Oleh karena itu, melihat dan mencari tahu filosofi masyarakat Kerinci tidak dapat dilepaskan dari falsafah tersebut. Maka dari itu, penulis akan melihat sejauh mana filosofi orang Kerinci ini dapat ditemukan dalam tradisi KS. 
Ada banyak penelitian yang dilakukan dalam KS. Penulis sebut saja beberapa seperti penelitian (Fitria, 2007)yang menemukan bahwa hilangnya makna asli upacara KS disebabkan oleh modernisasi. Pranata \& Ikhsan (2018) dan Sepdwiko (2016) melihat dari aspek kesenian (tari tauh) dan alat musik yang digunakan (gong) dalam KS. Pranata \& Ikhsan (2018) menemukan di dalam tari tauh ada makna dan simbol emik dan etik di dalam tarian tersebut. Sepdwiko (Sepdwiko, 2016) menemukan bahwa alat musik gong perunggu merupakan alat musik ritual di dalam KS. Beberapa penelitian lain seperti melihat naskah sebagai pusaka yang ada dalam KS (Syaputra Z.E., 2019) dan pengaruh KS terhadap perekonomian masyarakat Kerinci (Ramadani \& Qommaneeci, 2018) serta beberapa penilitian lain yang satupun belum ada melihat aspek filosofi masyarakat Kerinci yang termanifestasi di dalam KS. Oleh karena itu, penelitian yang melihat aspek filosofis dalam KS ini menjadi hal penting dan kebaruan dalam penelitian ini.

\section{LANDASAN TEORI}

Di dalam buku Tambo Sakti Alam Kerinci (Zakaria, 1984), orang Kerinci berpegang pada falsafah Adat Bersendi Syarak, Syarak Bersendi Kitabullah. Falsafah ini merupakan nilai/norma yang menjadi pedoman bagi tatanan kehidupan masyarakat Kerinci. Hal ini juga menandakan pandangan hidup dalam makna hubungan ke sesama manusia, Tuhan Maha Pencipta, dan alam semesta. Sebagai falsafah yang sama seperti etnis Minangkabau, ABSSBK menjadi sumber harapan dan kekuatan yang menggerakkan ruang lingkup kehidupan dan tolak ukur untuk melihat dunia dari ranah berbangsa dan bernegara (Yohanis, 2020). Kesamaan falsafah antara Kerinci dan
Minangkabau ini berdasarkan sejarah masuknya Islam di Kerinci yang dibawa oleh Siak Lengih dan Syaikh Samilullah yang berasal dari Minangkabau (Zakaria, 1984) dan beberapa ulama lainnya yang juga berasal dari Minangkabau.

Ada empat nilai-nilai (Yohanis, 2020) yang terkandung dalam falsafah ABS-SBK, yaitu (1) nilai keagamaan, (2) nilai kemanusiaan, (3) nilai demokrasi dan musyawarah, (4) nilai sosial kemasyarakatan (gotong royong). Keempat nilai ini menjadi pedoman bagi masyarakat Kerinci dalam menjalankan kehidupan sosial-kulturalnya. Falsafah ini dalam terminologi Durkheim disebut sebagai solidaritas mekanis (Morris, 1987), yaitu mengutamakan kepaduan kolektif, sebagaimana tercirikan sebagai filosofi ketimuran.

Kepaduan kolektif ini terlihat dari berbagai upacara tradisional yang dimiliki oleh masyarakat Kerinci seperti KS, upacara asyeik, upacara ngasap negri, upacara mandi balimau, upacara mandi basantan, upacara tuhaun kayei, upacara ayun luci, upacara naik haji, gotong royong (turun ke sawah, negak rumah, menggali saluran air, menarik kayu) (Helida, 2016). Keseluruh upacara tersebut mengandung nilai-nilai dalam falsafah ABS-SBK.

Dalam pepatah Kerinci (Zakaria, 1984), adeak balembago, undang bataliti, artinya lembaga ada karena adat, nilai-nilai/undang tidak akan jadi kalau tidak dengan teliti. Meneliti harus menurut adat, yaitu ABS-SBK. Segala sesuatu itu harus dijalankan dengan kebijaksanaan (Zakaria, 1984). Dengan kata lain, falsafah ini merupakan nilai budaya yang dimiliki oleh masyarakat Kerinci. Dikatakan sebagai nilai budaya karena ABS-SBK dapat dijadikan apa yang dikatakan oleh Koenjtaraningrat (Koentjaraningrat, 2004) sebagai konsepsi yang hidup dalam pikiran sebagian besar warga masyarakat 
sebagai sesuatu yang sangat bernilai di dalam hidup dan kehidupan.

Sistem nilai ini merupakan etikamoral yang di dalamnya terdapat norma sosial, sistem hukum, adat sopan-santun yang berfungsi sebagai tata-tertib kehidupan masyarakat. Dalam hal ini, adat-istiadat yang dimiliki menetapkan bagaimana masyarakat Kerinci bertindak secara tertib berdasarkan sistem nilai yang ada. Sistem nilai ini menurut Djamaris (Djamaris, 1993) dapat dilihat dari hubungan manusia tersebut dengan Tuhan, alam, masyarakat, manusia lain, dan dirinya sendiri.

\section{METODE PENELITIAN}

Untuk dapat melihat aspek filosofis masyarakat Kerinci di dalam tradisi KS, penelitian ini menggunakan metode kualitatif. Penelitian kualitatif dinyatakan oleh Creswell (2002) dengan metode pengumpulan data melalui partisipan/subjek dalam penelitian. Penelitian ini akan menggunakan desain etnografi yang dikemukakan oleh Creswell yang menyatakan bahwa prosedur penelitian kualitatif digunakan untuk menggambarkan, menganalisis, dan menafsirkan pola berbagi budaya bersama kelompok perilaku, keyakinan, dan bahasa yang berkembang seiring waktu.

Subjek penelitian akan diterapkan dengan teknik purposif sampling. Teknik ini digunakan oleh peneliti yang secara sengaja memilih individu dan situs untuk dipelajari dan dipahami fenomena sentralnya. Dari penelitian ini, peneliti memilih subjek penelitian yang bisa menjadi informan yang baik dan bisa memberi informasi data dalam penelitian. Dalam hal ini peneliti akan menjadikan tokoh adat Kerinci dan budayawan Kerinci sebagai subjek penelitian.
Adapun data yang dikumpulkan dan dianalisis adalah data yang diperoleh dari hasil observasi dan wawancara. Jenis observasi yang dilakukan adalah observasi langsung. Dawson (dalam Sudarsi dkk., 2019) menyatakan bahwa pengamatan langsung melibatkan pengamatan subjek dalam situasi tertentu dan sering menggunakan teknologi seperti kamera video dan peneliti tidak terlibat dalam kehidupan subjek yang sedang diamati.

Penelitian ini akan menerapkan wawancara semiterstruktur (Mackey \& Gass, 2015), yaitu peneliti menggunakan daftar tertulis pertanyaan sebagai panduan, sementara masih memiliki kebebasan untuk ngelantur dan probe untuk mendapatkan informasi lebih lanjut. Dalam hal ini peneliti akan mewawancari tokoh adat Kerinci dan budayawan Kerinci sebagai tindak lanjut dari data observasi dan kepastian akan kelengkapan data.

Teknik analisis data yang digunakan adalah pola siklus yang dikemukakan oleh Spradley (dalam Sudarsi et al., 2019) yaitu memuat langkah-langkah siklus yang dimulai dengan pemilihan proyek penelitian. Setelah itu, mengajukan pertanyaan etnografi dan mengumpulkan data etnografi. Proses selanjutnya, membuat catatan etnografi. Proses ini termasuk membuat catatan lapangan, mengambil foto/gambar, membuat peta, dan menggunakan cara lain untuk mencatat pengamatan peneliti. Data yang terkumpul dianalisis kembali guna mengetahui keabsahan data yang sesuai dengan kebutuhan penelitian.

\section{PEMBAHASAN}

\section{Tradisi Lisan Kenduri Sko}

Kenduri Sko merupakan satu dari beberapa tradisi lisan yang dimiliki oleh 
masyarakat Kerinci. Tradisi ini menjadi tradisi yang paling besar (Zakaria, 1984) mengingat keterlibatan masyarakat dan pembiayaan yang dibutuhkan. Biaya yang besar-pada masa dulu syaratnya adalah kbeu sikou breh sratauh 'seekor kerbau beras seratus' - terkadang membuat tradisi ini tidak lagi dilakukan setahun sekali setiap habis panen, tetapi bisa dilakukan dalam jangka waktu lima atau sepuluh tahun sekali. Akan tetapi, dibeberapa desa masih dilaksanakan setahun sekali.

Menurut Abas (1985) kegiatan ini biasanya dilaksanakan setelah panen terutama panen hasil sawah yang pada awalnya dilakukan untuk tujuan meningkatkan rasa kebersamaan antarsesama masyarakat yang memanen. Tujuan lain dari pelaksanaan kenduri sko ini, pertama, mengangkat dan menobatkan gelar kepada pemangkupemangku adat yang baru, sebagai pengganti pemangku adat yang telah berhenti sesuai dengan yang telah diatur oleh adat yang ada. Kedua, memohon keselamatan kepada Tuhan Yang Mahakuasa, juga kepada roh nenek moyang, roh para leluhurnya, agar diberi rezeki yang melimpah, karena setelah kegiatan kenduri sko ini penduduk setempat akan kembali ke sawah dan ladang. Ketiga, memeriksa kembali tanah-tanah pusaka yang lahir dari rumah pusakanya yang sekarang mungkin saja sedang berada pada tangan orang lain atau di dusun lainnya. Keempat, mengumpulkan semua sanak keluarga yang terpencar-pencar, berkumpul dalam rumah keluarganya dan rumah pusakanya.

Ada lima tahapan yang harus dilakukan untuk melangsungkan tradisi KS ini. Pertama, musyawarah dilakukan oleh pihak adat untuk menentukan siapasiapa yang akan dinobatkan gelar adat. Pada tahap ini orang-orang tuo tengganai melakukan musyawarah membahas siapa yang akan dinobatkan gelar adat dan siapa yang akan dipurnatugaskan dari kerjanya dalam mengurus adat-istiadat. Sebelum rapat terakhir dari tuo tengganai atau depati ninik mamak, pemilihan orang yang akan diberi gelar diajukan oleh pihakpihak keluarga dalam tingkatan keluarga inti. Orang yang dipilih melalui tingkat keluarga akan dipilih lagi melalui tingkat tengganai, dan terakhir diputuskan oleh ninik mamak. Dalam musyawarah ini ditentukan juga waktu, biaya, dan pelaksana tradisi KS tersebut. Kedua, tahap yang disebut sebagai minta arah, yaitu tahap meminta izin dan persetujuan dari pihak pelaksana kepada pihak adat untuk melangsungkan perhelatan KS. Ketiga, jika di dalam suatu daerah/desa tersebut masih memiliki benda-benda pusaka, maka akan dilangsungkan acara penurunan benda-benda pusaka. Pelaksanaan ini berlangsung sebelum acara penobatan gelar adat. Benda-benda pusaka ini biasanya tersimpan dalam sebuah peti dan diletakkan di atas ptaih atau disebut sebagai loteng (Zakaria, 1984) dari sebuah rumah adat yang disebut sebagai rumah gedang. Penurunan benda-benda pusaka ini dilakukan dengan cara menyediakan sajian yang biasanya berupa nasi putih, nasi kuning dan hitam, telur ayam, air limau, dan lain-lain.

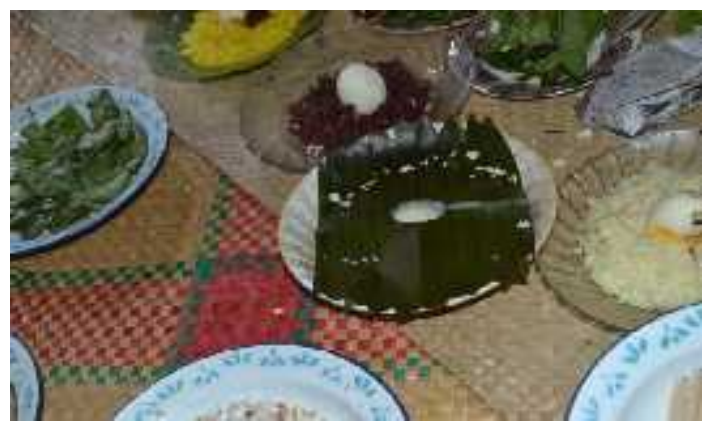

Gambar 1. Sajian untuk penurunan benda pusaka. (foto: Ricky A. Manik)

Benda-benda pusaka itu kemudian dibersihkan dengan air yang sudah diberi 
limau dan berbagai bunga yang membuat air tersebut menjadi wangi. Zakaria (Zakaria, 1984) mengatakan bahwa penyucian benda-benda pusaka tersebut adalah agar orang sebagai keturunan dari nenek moyang pemilik pusaka itu juga menyucikan dirinya. Suci dari segala kesalahan-kesalahan yang pernah diperbuat, baik kepada sesama, orang tua, dan kepada nenek moyang. Pada kesempatan tersebut, mereka bersaudara saling memaafkan untuk dapat menghapus dosa-dosa yang sudah diperbuat, terutama kepada Tuhan Yang Maha Esa.

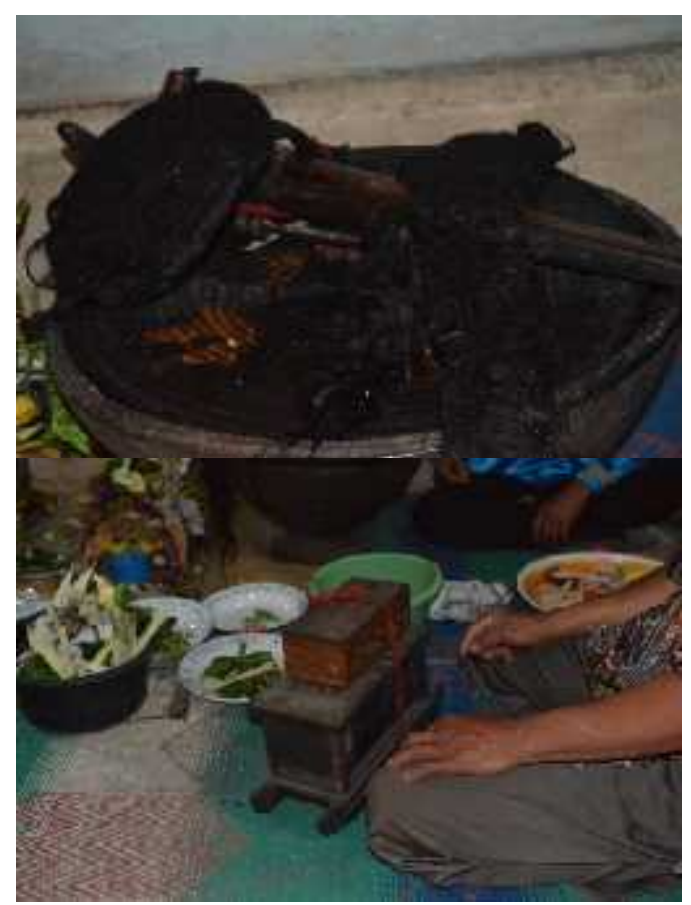

Gambar 2. Pusaka berupa keris, pedang, tameng, rambut panjang dan dua buah kotak. (foto: Ricky A. Manik)

Setelah benda pusaka itu dibersihkan, benda itu akan diperlihatkan kepada siapa saja yang hadir dan hendak melihatnya. Apabila saat pembersihan itu akan dilakukan penobatan gelar adat, benda pusaka itu akan dibawa ke tempat di mana penobatan akan berlangsung. Pusaka itu akan diperlihatkan kepada seluruh masyarakat dan tamu yang hadir. Di atas benda pusaka itu pula, gelar adat akan diberikan kepada yang akan dikukuhkan.

Keempat, penobatan gelar adat kepada orang yang telah disepakatidalam hal ini adalah orang yang dianggap cakap dan pintar-dari anak kemenakan pewarisnya. Hal ini juga merupakan hak yang mesti diberikan kepada penerima gelar. Adapun aturan yang harus dilakukan untuk dapat mengukuhkan gelar adat ini adalah memotong kerbau seekor dan memasak beras seratus gantang (1 gantang sama dengan 12 canting/kaleng susu, 4 canting sekitar 1kilogram lebih, jadi, 1 gantang sekitar 3kilogram lebih). Kelima, dari seluruh rangkaian tradisi ini adalah menikmati makan bersama antara pemimpin adat, seluruh masyarakat desa dan pihak luar yang datang. Lemang (penganan ketan yang dimasak menggunakan bambu dan dihias dengan kertas minyak) yang dimasak oleh masyarakat kemudian dibagikan kepada masyarakat dan tamu yang datang.

Tradisi KS ini berlangsung selama satu minggu. Banyak kegiatan yang dihadirkan di dalam tradisi tersebut, mulai dari pertandingan olah raga seperti takraw, catur, dan domino hingga kesenian-kesenian tradisi, seperti tari iyo-iyo, tari asyiek, tari rangguk, nyanyian daerah dan pencak silat. Hampir seluruh masyarakat desa terlibat di dalamnya. Akan tetapi, zaman modern telah menggeser hiburan yang dilaksanakan dalam KS, hiburan yang berlangsung sudah menggunakan keyboard dengan musik-musik dangdut dan remix, pelelangan bir dan nyanyiannyanyian yang tidak lagi lagu tradisional. Bahkan syarat kbeu siko behih sratauh 'kerbau seekor beras seratus' untuk dimakan pada acara puncak sudah tidak menjadi keharusan. Tentu saja modernisasi tidak dapat dihindari, tetapi yang paling utama dari tradisi ini adalah nilai filosofi yang tidak 
boleh hilang dan diketahui oleh generasigenerasi berikutnya sehingga hal-hal yang fundamental di dalam tradisi ini masih dipegang teguh oleh masyarakat Kerinci.

\section{Nilai Filosofi Keagamaan dalam Kenduri Sko}

Masuknya beberapa agama bagi masyarakat Kerinci dengan berbagai peninggalan baik artefak dan kebudayaannya memberi pengaruh yang kuat sampai saat ini. Zakaria (Zakaria, 1984)menyebutkan bahwa bentukbentuk kesenian Kerinci dipengaruhi oleh animisme, hinduisme dan islamisme. Percampuran kebudayaan tersebut bahkan belum dapat dipisahkan. Hal ini masih bisa ditemukan pada upacara pengobatan yang disebut dengan asyiek dan Kenduri Sko. Kedua tradisi tersebut masih menggunakan sesajen dan kemenyan untuk memberi penghormatan kepada leluhur/nenek moyang. Adapun mantra-mantra yang digunakan dan lebih disebut sebagai doa acap kali menyebut nama Allah dan rasul-Nya.

Seperti yang telah ditulis sebelumnya, KS merupakan tradisi selepas panen yang mengungkapkan rasa syukur atas pusaka peninggalan nenek moyang dan berkah hasil panen yang diberikan oleh Tuhan Yang Maha Pengasih. Masuknya agama Islam yang lebih diterima oleh orang Kerinci menurut Sabdanur (wawancara, 12 Februari 2020) membuat tradisi KS harus berlandaskan agama Islam. Memotong seekor kerbau dan memasak hasil panen untuk dimakan bersama dilakukan dengan doa-doa keagamaan. Hal ini menandakan bahwa orang Kerinci memiliki nilai keagaaman yang kuat dan mengucap syukur atas apa yang dianggap sudah diberikan kebaikan/berkah berupa hasil panen yang melimpah oleh Tuhan. Selain itu, melakukan KS menjadi kewajiban bagi masyarakat karena jika tidak bersyukur atas panen tersebut akan mendapat hasil yang tidak baik (Ramadani \& Qommaneeci, 2018). Selain sebagai ucapan syukur, KS ini merupakan permohonan agar pendapatan dan hasil panen masyarakat berlipatganda di tahun yang akan datang (Ramadani \& Qommaneeci, 2018). Kemudian hasil panen yang dimasak dan dimakan bersama menandakan akan nilai-nilai kebaikan, mengasihi, dan berbagi kebahagiaan kepada orang lain yang tentu saja merupakan ajaran dalam agama yang dianut, yaitu Islam.

Hal terkait nilai filosofi keagaaman juga dapat dilihat dari pepatah-petitih yang disampaikan pada saat penobatan gelar adat, seperti kutipan di bawah ini:

Depati: Masauk pado karang stio ngan samangkauk. Sapo ngising kno miang, sapo nguyang kno rbeah, sapo mancak mulih utang, sapo nindeih mulih garoih. Ideak bulieh nuhok kawang saireing, ideak bulieh nguntein kae dalon lipatan. Ideak bulieh bakuroak bakandon daleang, ideak bulieh pepak di luo unceing di dalon. Kalou diparbuot, padoi ditanang lalang tumbouh, kunyaet ditanang puteih isi, anak dipangkau jadi bateu. Ngadeak ka ilei dikutuk Tuhang, ngadeak ka mudeik dikutuk Tuhang, dikutuk qur'an 30 jeuh dimakon biso kawai. Ka dateh ideak bapucauk, ka bawoh ideak baurak, di tengoah di jarum kumbang. Dibageh ingak pado sagalo anok janteang anok batinoa, jiko awak ideak dilabeuhkan glea, dijadikan rekak dengon rekik, dijadikan rujuk dingon undou. Manggulung si lengan bajeu, nyingkak kaki sirwang, nambak bateu di balei, manikang kapalo karto, ngato awak di luo adeak di luo pusko, ngandang saumo ideuk. 
Terjemahan: Masuk pada karang setia yang semangkuk. Siapa mengesah kena miang, siapa menggoyang kena rebah, siapa berbuat salah beroleh utang, siapa menindih beroleh garis. Tidak boleh menohok kawan seiring, tidak boleh menggunting dalam lipatan. Tidak boleh berkurung berkandang dalam, tidak boleh pepat di luar runcing di dalam. Kalau diperbuat, padi ditanam ilalang tumbuh, kunyit ditanam putih isi, anak dipangku jadi batu. Menghadap ke hilir dikutuk Tuhan, menghadap ke mudik dikutuk Tuhan, di tengah di makan bisa kawi, dikutuk Al-Qur'an 30 juz, ke atas tidak berpucuk, ke bawah tidak berurat, di tengah di jarum kumbang. Diberi ingat kepada semua anak jantan-anak betina, jika kita tidak diberikan gelar, dijadikan rekak dengan rekik, dijadikan rujuk dengan mundur. Menggulung si lengan baju, menyingkat kaki celana, melemparkan batu di balai, menikam kepala kerta mengatakan kita di luar adat, di luar pusaka, mengandang seumur hidup.

Karang setia menjadi norma yang disepakati secara adat oleh masyarakat Kerinci. Norma/nilai ini mesti dipedomani oleh mereka yang telah dikukuhkan gelar adat. Apabila tidak dilaksanakan maka akan menerima konsekuensinya sendiri berdasarkan ketentuan yang berlaku. Akan tetapi, norma/nilai yang ditentukan oleh adat tersebut tetap berlandaskan pada agama. Nilai-nilai adat diselaraskan dengan norma agama. Bagi mereka yang mendapatkan gelar adat akan menjadi teladan dalam perilaku masyarakatnya.

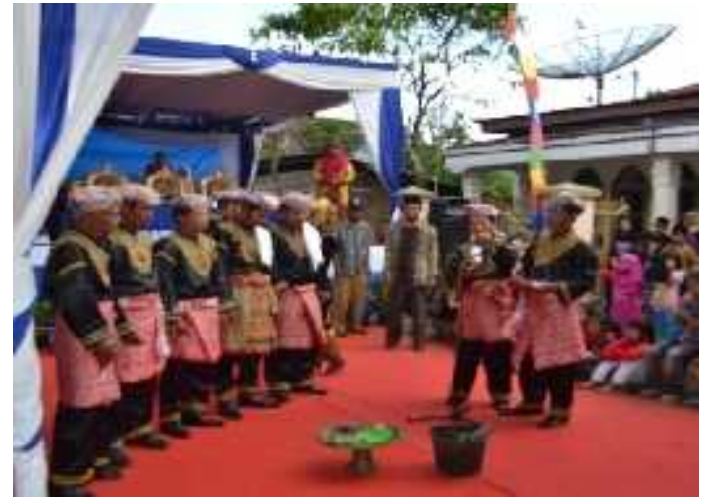

Gambar 3. Penobatan gelar adat kepada orang yang sudah dipilih secara kerapatan.

(foto: Ricky A. Manik)

Di dalam pepatah tersebut, orang yang dikukuhkan gelar adat tidak boleh melanggar atau menyimpang dari norma yang dibacakan tersebut. Nilai-nilai seperti tidak boleh menohok, menggunting dalam lipatan atau berkhianat dan melakukan perusakan atas apa yang sudah disusun rapi, tidak boleh melakukan sesuatu demi keuntungan sendiri, tidak boleh juga hanya sewenang-wenang di dalam sementara di luar tidak berani berbuat apa-apa. Semua yang melanggar itu akan mendapatkan hal yang tidak baik di dalam kehidupannya kelak. Dalam konsep agama ini dinamakan sebagai perbuatan dosa. Apa yang dilakukan tidak akan mendatangkan hasil yang baik, padi ditanam tumbuh ilalang, kunyit ditanam putih isi, anak dipangku jadi batu. Tuhan dan kitab suci Al-Quran akan mengutuk perbuatan-perbuatan yang melanggar nilai-nilai tersebut. Nilai-nilai agama akan menjadi pedoman dalam perilaku para sko tiga takah yang dinobatkan tersebut.

Sekalipun penggunaan pengukuhan dengan cara adat, semuanya masih berlandaskan nilai-nilai keagamaan. Mereka yang menjabat selaku pemangku adat justru paling tidak boleh melakukan penyimpangan dari nilai/norma/aturan adat yang berlandaskan agama, sesuai dengan falsafah ABS-SBK. Mereka menjadi 
orang-orang yang membawa kepada kehidupan yang harmonis di dalam masyarakatnya. Jika ada masyarakat yang melakukan penyimpangan dari nilai/norma/aturan yang berlaku, para pemangku adat yang memiliki wewenang dalam membuat keputusan hukumnya. Para pemangku adat ini juga memiliki peran dalam banyak sistem yang ada di masyarakat, seperti perkawinan, rumah tangga, kekerabatan, kemasyarakatan, pemerintah, warisan, hukum, dan ekonomi. Meskipun dalam berbagai sistem yang dimiliki oleh masyarakat Kerinci tersebut dilakukan secara adat, nilai-nilai agama Islam yang diyakini tetap menjadi landasan utamanya.

Koentjaraningrat

mengatakan bahwa aspek religiusitas merupakan bagian dari kebudayaan. Ia membaginya dalam beberapa konsep, salah satunya adalah sistem ritus dan upacara yang merupakan usaha manusia untuk mencari hubungan dengan Tuhan, dewa-dewa, atau makhluk halus yang mendiami makhluk gaib. KS menjadi pembayangan masyarakat Kerinci akan kebaikan Tuhan yang telah memberi berkahnya (hasil panen) kepada umat yang kemudian diimplementasikan dalam upacara atau tradisi. Keyakinan akan hal ini menjadi sikap religius yang masih terus dipertahankan.

\section{Nilai Filosofi Kemanusiaan dalam Kenduri Sko}

Nilai diwujudkan dalam bentuk norma sebagai landasan manusia dalam bertindak. Manusia bertindak berdasar dan didorong oleh nilai yang diyakininya. Nilai kemanusiaan dapat menjadikan seseorang atau lebih untuk bertindak dan bersikap guna mencapai pribadi yang manusiawi. Hal demikian dapat dilihat dari sistem adat yang dimiliki oleh masyarakat Kerinci. Adat berfungsi sebagai sistem nilai/norma/aturan dalam perilaku masyarakat pemiliknya. Sistem adat mengatur mulai dari sistem perkawinan, rumah tangga, kerabat, masyarakat, pemerintahan, warisan, hukum, hingga ekonomi masyarakat yang kesemuanya menyangkut perihal kemanusiaan.

Selain sebagai ucapan syukur kepada Tuhan Yang Maha Pengasih, KS merupakan bentuk penghargaan dan ucapan syukur kepada nenek moyang yang telah memberikan pusaka warisan berupa tanah yang dapat digarap seperti kebun dan sawah. Penghargaan kepada leluhur adalah penghargaan atas eksistensi manusia. Art-Ong Jumsai dan Na-Ayudhya (dalam Sukayasa \& Awuy, 2014) mengatakan bahwa nilai-nilai kemanusiaan (human value) memiliki lima pilar, yaitu kebenaran, kebajikan, kedamaian, kasih sayang, dan tanpa kekerasan. Menghargai keberadaan orang lain (leluhur) merupakan salah satu pilar di dalam nilai-nilai kemanusiaan, yaitu kasih sayang. Secara tidak langsung, KS mengedukasi untuk menghargai orang lain, menghargai manusia. Mengadakan tradisi KS menunjukkan bahwa orang Kerinci mengaktualisasikan kasih sayang mereka kepada leluhur. Ditilik dari keberlangsungan KS yang terus diadakan, menandakan bahwa filosofi kemanusiaan ini masih terus dijaga dan dipertahankan.

Ada banyak nilai-nilai kemanusiaan yang bisa ditemukan di dalam tradisi $\mathrm{KS}$ ini, seperti misalnya bekerja sama, tenggang rasa, menghormati orang lain, adanya persamaan hak dan lain sebagainya. Nilai kemanusiaan ini bisa dilihat dari awal proses KS ini ketika akan diselenggarakan, yaitu melaksanakan musyawarah dalam menentukan siapa yang akan diberikan gelar adat dan menentukan hari serta 
penyelenggaranya. Proses musyawarah merupakan proses dalam menjunjung tinggi harkat manusia. Bahwa dengan bermusyawarah berarti ada proses penghargaan terhadap orang lain, hak yang sama dalam berpendapat seperti menerima dan tenggang rasa berbagai pendapat yang berbeda dan menyatukannya. Penentuan siapa yang akan dinobatkan gelar juga merupakan kebijaksanaan yang diputuskan secara bersama. Jika dalam memutuskan orang yang akan menerima gelar adat hanya berdasarkan keputusan dengan kepentingan tertentu, seperti misalnya menerima uang dari orang yang berkepentingan akan gelar adat itu, secara politis pada dasarnya sudah menghilangkan nilai-nilai kemanusiaan.

Pemberian gelar adat kepada orang yang berhak dalam mengatur tatanan kehidupan adat masyarakat Kerinci merupakan penanda akan nilai-nilai kemanusiaan, seperti harus mematuhi nasihat yang diberikan di dalam pidato pengukuhan gelar adat.

Depati: Adepun kamai ineih melakaukan buot dingon karang setio, di ateh baserau ngan baimbea anok janteang anok batino, kepado umoh kapado tango, kapado laheik kapado jajo, manganengohkan tando kbea sikou breh sratauh, ndok jadi Depatai dan Permentai.

Terjemahannya: Adapun kami ini melakukan buat dengan karang setia, di atas berseru dan berimbau anak jantan anak perempuan. Kepada rumah, kepada tanga, kepada larik, kepada jajar mengenengahkan tanda kerbau seekor, beras seratus hendak jadi Depati dan Permenti.

Bagi para pemangku adat yang diberi gelar, haruslah mematuhi nasihat yang tertuang dalam bentuk perjanjian karang setia. Perjanjian adat ini harus dilaksanakan dan jika tidak, akan mendapatkan hal yang tidak baik di dalam kehidupan, baik secara individu maupun kaumnya. Mematuhi norma/nilai/aturan yang diberikan merupakan nilai kemanusiaan yang harus dipedomani oleh para pemangku adat.

Pada kegiatan penurunan benda pusaka, nilai kemanusiaan yang dapat ditemukan berupa selain menghormati leluhur, menjaga nama baik keluarga, mengakui kesalahan dan meminta maaf atas perbuatan yang salah tersebut, menghormati orang yang lebih tua dan menghargai orang yang sebaya serta yang lebih muda. Penurunan benda pusaka dengan merawat, menjaga, dan membersihkannya adalah bentuk penghargaan kepada leluhur yang telah mewariskan pusaka kepada keluarga atau kaum. Sedangkan, mengakui kesalahan dan meminta maaf atas perbuatan salah merupakan bentuk intropeksi yang dilakukan oleh manusia dalam melaksanakan nilai-nilai kedamaian. Secara tidak langsung bagi masyarakat Kerinci, saling memaafkan antara keluarga di saat penurunan pusaka adalah manifestasi akan nilai-nilai kemanusiaan tersebut.

Nilai kemanusiaan lain yang bisa ditemukan dalam KS ini adalah dengan mengadakan pesta bersama dengan kerabat keluarga dan masyarakat desa sampai ke tamu yang datang untuk menyaksikannya. Menikmati hasil panen secara bersama-sama merupakan bentuk sikap sosial manusia untuk saling berbagi kebahagiaan kepada sesama. Memperoleh berkah hasil panen yang melimpah tidak dinikmati sendiri melainkan dinikmati bersama-sama. Ada nilai kebersamaan, kasih sayang, saling membantu, dan menghargai keberadaan masyarakat di mana manusia itu berada.

Makan bersama sebagai akhir dari perhelatan tradisi $\mathrm{KS}$ ini merupakan 
perilaku saling berbagi dan bergembira bersama. Makan bersama tanpa ada sekat dan status sosial menjadikan kegiatan ini memiliki nilai-nilai kemanusiaan akan persamaan derajat, memiliki hak dan kewajiban selaku manusia yang sama. Tidak ada perbedaan, baik suku, agama, dan ras, dalam hal makan bersama ini. Seluruh undangan yang hadir diajak untuk makan bersama-sama dengan masyarakat yang mengadakan tradisi KS tersebut.

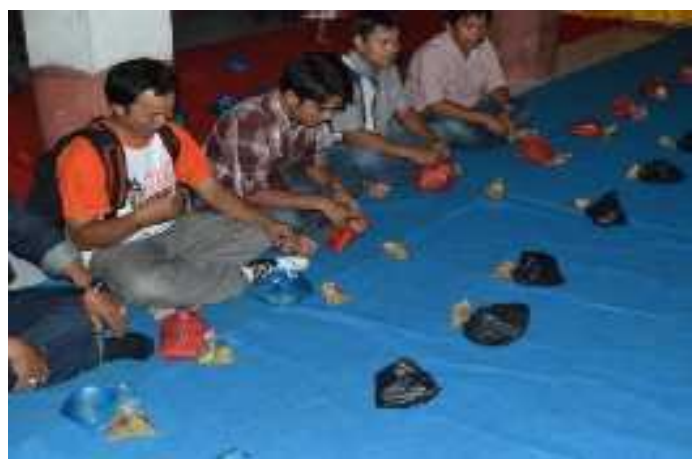

Gambar 4. Makan bersama dalam acara tradisi Kenduri Sko di Desa Kotoiman, Kab.Kerinci. (Foto: Ricky A. Manik)

Secara keseluruhan, tradisi KS memperlihatkan bahwa nilai-nilai kemanusiaan sangat dijunjung tinggi oleh masyarakat Kerinci. Tradisi KS menjadi penanda bahwa orang Kerinci sangat meninggikan harkat dan martabat manusia. Adat yang dipegang teguh sebagai filosofi kehidupan merupakan nilai budaya yang selalu menjadi pedoman tertinggi dalam perilaku masyarakat. Seperti yang dikatakan Djamaris (1993), di dalam tradisi KS nilai-nilai tersebut dipraktikan, yaitu hubungan manusia dengan Tuhan, manusia dengan alam, manusia dengan masyarakat atau manusia lainnya, dan manusia dengan dirinya sendiri.

\section{Nilai Filosofi Demokrasi dan Musyawarah dalam Kenduri Sko}

Bumi Sakti Alam, Kerinci, memiliki alam dengan wilayah pertanian yang sangat subur dalam memberikan kesejahteraan bagi masyarakatnya. Kerinci dikenal sebagai penghasil beras yang cukup baik (Zakaria, 1984) dan masyarakat adat yang terbilang religius. Hidup dengan alamnya yang subur dan sistem adat serta keagamaan yang kuat telah membentuk satu kesatuan nilai demokrasi bagi masyarakat Kerinci. Ketiga hal tersebut tidak bisa dilepaskan karena nilai-nilai itu saling berkaitan, saling mempengaruhi, dan membentuk ikatan yang kuat dalam membangun tatanan kehidupan masyarakat Kerinci. Nilai tersebut dapat berupa nilai kebersamaan, musyawarah mufakat, persamaan, kebebasan berpendapat, dan keadilan.

Implementasi nilai-nilai demokrasi dan musyawarah terlihat dalam penentuan orang-orang yang akan diberikan gelar adat. Di dalam masyarakat Kerinci ada empat jenis jabatan tertinggi yang menentukan tatanan kehidupan masyarakatnya, yaitu Depati Ninik Mamak, Orang Tua Cerdik Pandai, Alim Ulama, dan Hulubalang atau pemuda (Zakaria, 1984). Kenduri skosebagai media jabatan itu dipilih dan ditentukan dengan cara bermusyawarah. Sekalipun gelar Ninik Mamak adalah gelar tertinggi di dalam struktur masyarakat tersebut, ia tidak bisa memutuskan sendiri sesuai kepentingannya. Jalan musyawarah harus dilakukan, berunding dengan pemangku jabatan lain guna mendapatkan keputusan yang bijaksana untuk kebersamaan.

Kelsen (dalam Faturahman, 2018) menyatakan esensi demokrasi terdapat pada adanya kompromi dalam menyatukan pendapat yang berbeda. Prinsipnya ada pada penyelesaian konflik melalui norma yang tidak seluruhnya sesuai dengan kepentingan dari salah satu pihak, dan juga tidak seluruhnya bertentangan dengan 
kepentingan lainnya. Masing-masing jabatan yang ada dalam struktur masyarakat Kerinci tidak dapat memutuskan berdasarkan kepentingan kelompoknya, tetapi melakukan kompromi atas pendapat-pendapat yang berbeda sehingga terjadi kesepakatan bersama dan dipraktikkan di dalam kehidupan masyarakat.

Nilai-nilai demokrasi dalam masyarakat dapat dilihat dari pola perilaku masyarakat atau warga negara dalam mempraktikan konsep pemerintahan dari rakyat, oleh rakyat, dan untuk rakyat. Dalam KS praktik demokrasi terjadi seperti kesadaran masyarakat akan adanya pemilu. Proses pemilihan pemangku adat yang akan diberi gelar terjadi melalui mekanisme pemilihan dari kaum. Pemilihan orang yang akan mewakili kaum tidak dapat dilepaskan dari adat yang merupakan warisan gelar. Warisan gelar ini bisa didapat oleh baik anak jantan (kemenakan laki-laki) maupun anak betina (kemenakan perempuan). Apabila di dalam kaum tersebut memiliki banyak kemenakan, kemenakan yang layak dipilih untuk mendapatkan gelar harus berdasarkan kriteria adat yang sudah ditentukan, seperti "langsing kokoknya" (orang yang pandai berbicara), "kembang sayapnya" (berlaku adil), "sibar ekornya" (memahami pendapat yang berbeda), "besar paruh" (pengetahuan adat yang luas), "lebar dada" (tenang, sabar, berhati lapang), dan "runcing taji" (tahu hukum dan peraturan) (Zakaria, 1984).

Di dalam adat Kerinci, mekanisme demokrasi dan musyawarah dikenal dengan nama "kerapatan". Musyawarah dalam masyarakat Kerinci terbagi dalam beberapa "kerapatan", mulai dari rapat rumah tangga yang dihadiri oleh seluruh keluarga, rapat para tengganai yang dihadiri oleh beberapa kepala keluarga yang dipimpin oleh tengganai, rapat ninik mamak yang dihadiri oleh para tengganai dan dipimpin oleh ninik mamak, dan rapat orang empat jenis yang dihadiri oleh seluruh orang empat jenis yang dipimpin oleh ninik mamak (Zakaria, 1984). Proses penentuan orang yang akan diberi gelar adat akan melalui mekanisme kerapatan tersebut. Hal ini menandakan bahwa perilaku masyarakat Kerinci dari institusi sosial terkecil yakni keluarga dalam menentukan perwakilan keluarga atau kaum telah mengimplementasikan nilai-nilai demokrasi.

Musyawarah untuk menghasilkan kata mufakat merupakan kunci dalam sistem demokrasi masyarakat Kerinci. Hal ini dilakukan sejak dari keluarga hingga ke masyarakat umum. Menurut Sabdanur (wawancara, 12 Februari 2020) segala masalah yang muncul di masyarakat Kerinci, seperti perkelahian, perselingkuhan, pencurian, perceraian, dan sebagainya diselesaikan dengan cara adat yang mengedepankan nilai-nilai musyawarah dan demokrasi. Hal ini menunjukkan akan adanya demokrasi yang dipengaruhi oleh sistem budaya masyarakat Kerinci yang mengutamakan kesepakatan bersama dalam menyelesaikan masalah yang terjadi. Seluruh proses dan mekanisme yang dilakukan dalam pemilihan orang yang akan diberi gelar adat dalam KS secara tidak langsung telah menjalankan nilainilai kebersamaan karena dilakukan secara bersama, nilai kebebasan dalam berpendapat dan memberikan keadilan bagi masyarakatnya secara musyawarah mufakat.

Selain itu, kategori nilai demokrasi yang dapat ditemukan dalam KS dapat merujuk pada pembagian yang dikatakan oleh Mayo (Hapsari, 2015) sebagai berikut.

1. Menyelesaikan persoalan secara damai dan melembaga. 
2. Menjamin terselenggaranya perubahan secara damai dalam suatu masyarakat yang sedang berubah.

3. Menyelenggarakan pergantian pemimpin secara teratur.

4. Membatasi pemakaian kekerasan sampai taraf yang minimum.

5. Mengakui serta menganggap wajar adanya keanekaragaman (diversity).

6. Menjamin tegaknya keadilan.

Implementasi nilai demokrasi dan musyawarah yang dilakukan masyarakat Kerinci dalam KS menjadi hal yang sangat penting mengingat perubahan zaman yang dapat membawa dampak pada sosialkultural masyarakat, seperti datangnya etnis lain dan terjadi perkawinan dengan etnis lain tersebut. KS dapat menjadi sarana dalam memberi kesadaran masyarakat yang terus dinamis guna mempertahankan dan menumbuhkan nilai-nilai demokrasi di dalam tatanan kehidupannya. Menurut Inglehart (2006), budaya memberikan peran besar dalam terciptanya demokrasi, karena demokrasi tumbuh subur di dalam satu konteks sosial dan budaya. Dewey (Price, 2007) menganggap demokrasi adalah hal yang sangat utama di dalam kehidupan yang disebutnya sebagai way of life.

Demokrasi sebagai nilai fundamental menjadi pandangan hidup masyarakat Kerinci yang diwariskan masyarakatnya secara turun-temurun dan termanifestasikan dalam KS. Tradisi ini menjadi efektif sebagai cara utama dalam mentransformasikan nilai-nilai demokrasi.

\section{Nilai Filosofi Sosial Kemasyarakatan dalam Kenduri Sko}

Pelibatan seluruh masyarakat di dalam tradisi KS menandakan adanya kesadaran masyarakat akan nilai sosial kemasyarakatan yang mereka miliki.
Bagi orang Kerinci KS sudah menjadi identitas kebanggaan mereka yang tidak dimiliki oleh etnis lain. Kerja sama baik dari muda hingga para tetua dan laki-laki hingga perempuan saling bahu-membahu melakukan tugas dan fungsinya masingmasing. Dalam perhelatan ini, KS merupakan hal baik yang diyakini oleh masyarakat Kerinci.

Bagi masyarakat Kerinci, KS adalah tradisi yang baik untuk dilakukan karena nilai-nilai kebaikan banyak dipraktikkan di dalam tradisi tersebut. Seperti yang sudah dijelaskan dalam pembahasan bahwa di dalam KS mengandung nilai-nilai penghargaan atau penghormatan kepada Tuhan dan leluhur, nilai kerja sama, nilai tenggang rasa dan menghormati orang lain, kesamaan hak dan keadilan, dan lainlain.Semua itu merupakan nilai-nilai kebaikan. Keyakinan akan nilai kebaikan tersebut mewujud dalam masyarakat dengan bersama-sama dan bergotongroyong untuk menyelenggarakan KS.

Menurut Nukman (wawancara, 5 Februari 2020), pemantik tradisi KS untuk dilaksanakan dikarenakan adanya gelar adat yang akan diberikan. Pascapanen dan penurunan pusaka untuk dibersihkan bukan menjadi yang utama tradisi tersebut dilakukan, tetapi momentum pascapanen merupakan media untuk pengangkatan gelar adat tersebut diadakan. Gelar adat pun belum dapat dilaksanakan sebelum panen tiba. Apabila masa panen jatuh dan tidak ada orang yang akan dinobatkan gelar adat, maka yang berlangsung adalah tradisi Kenduri Sudah Tuai, yaitu perhelatan setelah habis panen. Adapun penyebab dinobatkannya seseorang mendapatkan gelar adat adalah terjadinya pergantian orang yang sudah meninggal atau dianggap sudah purnatugas. Oleh sebab itu, dasar penobatan gelar adat ini menurut penulis adalah yang utama. Kaum yang berada di luar dari pemilik 
pusaka baik pusaka gelar maupun pusaka tanah yang bisa digarap tidak dapat diberikan gelar adat tersebut kepadanya.

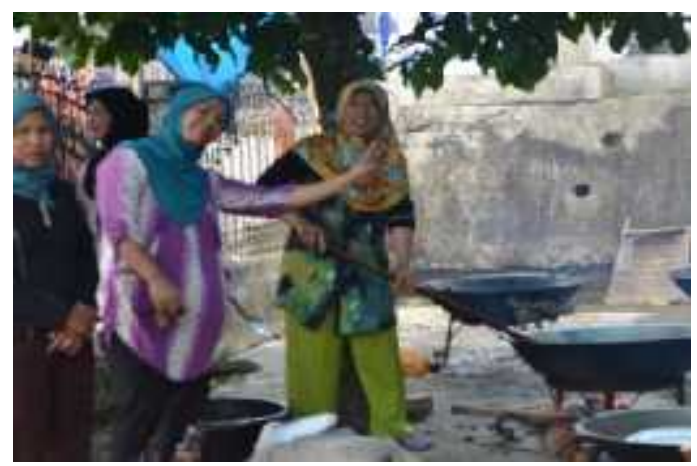

Foto 5. Para ibu bergotong-royong memasak buat makan bersama di acara Kenduri Sko. (foto: Ricky A. Manik)

Bagi orang Kerinci, adat adalah hal baik dalam menata keharmonisan kemasyarakatan. Melakukan adat meruapakan perbuatan baik untuk kemanusiaan. Menunjuk dan menentukan orang-orang yang memiliki gelar adat adalah upaya ke arah kebaikan tersebut. Menurut Nukman (wawancara, 5 Februari 2020), mendapatkan gelar adat dan melakukannya tidak ada kepentingan ekonomi, semua dilakukan dengan sukarela. Sikap sosial yang dilakukan oleh pemangku gelar adat dalam mengurus masyarakatnya adalah bentuk kebaikan didedikasikan kepada khalayak ramai, bukan kepada diri sendiri.

Selain itu, orang yang memiliki gelar adat harus menjadi teladan dalam sikap dan perilakunya di masyarakat. Mereka menjadi contoh bagaimana nilainilai kebaikan tersebut dipraktikkan, mulai dari nilai-nilai agama, adat masyarakat, dan individu (sebagai seorang yang ulet, telaten, rajin, pekerja keras, dan sebagainya). Hal ini dapat dilihat dari pepatah yang diberikan kepada para pemangku gelar bahwa mereka harus berperilaku sesuai dengan nilai dan ketentuan yang tertuang di dalam karang setia. Jika para pemangku gelar tersebut tidak melakukan hal yang sesuai dengan nilai yang ada di dalam karang setia, mereka, kaum dan bahkan masyarakat, akan mendapatkan akibat yang tidak baik. Nilai-nilai yang terdapat di dalam karang setia menjadi penggambaran yang diinginkan, sesuatu yang pantas, dan berharga oleh masyarakat Kerinci. Nilai sosial yang ada di dalam KS ini juga menjadi alat pengontrol perilaku manusia.

Hal yang dianggap baik juga di dalam KS adalah melakukan ucapan syukur kepada Tuhan dan kepada nenek moyang. Panen yang diperoleh dari hasil tanah yang dimiliki tidak dinikmati sendiri melainkan dirasakan bersama. Nilai kebersamaan dan berbagi kebahagiaan atas berkah yang didapat merupakan nilai sosial yang secara tidak langsung dipraktikkan oleh masyarakat Kerinci melalui KS. Konsistensi masyarakat untuk melaksanakan KS ini pun merupakan perwujudan nilai sosial akan kepatuhan dan kesetiaan manusia terhadap Tuhan dan sesama. Sekalipun KS tidak tetap pelaksanaannya, tetapi masyarakat Kerinci tetap melangsungkan kenduri di saat habis tuai padi.

Nilai sosial masyarakat yang lain dapat kita temukan dalam KS adalah suka menolong, hidup rukun, dan bekerja sama. Setiap kali akan diadakan KS, warga masyarakat secara otomotis akan saling tolong-menolong dalam menyelenggarakan KS. Pihak laki-laki biasa saling tolong-menolong dalam menyiapkan tenda, menegakkan tiang bendera karamentang (bendera sebagai penanda dan pemberitahuan kepada khalayak bahwa di lokasi tersebut berlangsung KS), dan berbagai piranti kebudayaan yang lainnya. Sedangkan, pihak perempuan tolong-menolong dalam membuat masakan, seperti memasak nasi, membuat gulai daging, dan memasak lemang. Bahkan pihak laki-laki atau perempuan bantu- 
membantu dalam pekerjaannya masingmasing.

Keberlangsungan KS dengan membawa berbagai nilai-nilai kebaikan di dalam masyarakatnya menandakan bahwa masyarakat Kerinci pada prinsipnya memegang teguh akan kerukunan antarmasyarakatnya. Mengangkat gelar adat dan melakukan nilai-nilai agama dan adat secara seiring di dalam KS menandakan bahwa masyarakat memiliki horizon harapan bersama akan keharmonisan baik di dalam keluarga atau di masyarakatnya. Tentu saja nilai sosial ini juga dapat dijumpai pada seni-seni tradisi yang lain, seperti pengobatan asyiek, perkawinan, menaikkan rumah, membangun rumah, bercocok tanam, naik haji, kematian, dan sebagainya. Semua itu memperlihatkan bagaimana orang Kerinci sangat menjunjung tinggi nilai sosial masyarakatnya.

Nilai gotong-royong adalah nilai yang paling nyata terlihat di dalam kehidupan masyarakat Kerinci. Hal ini terlihat dari banyaknya tradisi kemasyarakatan yang dimiliki oleh orang Kerinci. Tradisi-tradisi kebudayaan yang dimiliki oleh masyarakat Kerinci mengandung nilainilai kerja sama atau bergotong royong. Dari sistem adat yang mereka miliki dengan berbagai peran di dalamnya menandakan bahwa satu peran dengan peran lainnya bekerjasama dalam membangun keharmonisan masyarakatnya. Implementasi nilai kerja sama/gotong-royong yang ada di dalam KS dapat dilihat dari awal perhelatan ini akan diadakan hingga selesai. Semuanya adalah bentuk kerja sama dan bahumembahu antarmasyarakat Kerinci sebagai identitas sosialkultural.

\section{PENUTUP}

Berdasarkan pembahasan pada penelitian ini, penulis menyimpulkan bahwa tradisi KS merupakan tradisi yang dilakukan bila ada orang yang akan diberikan gelar terlebih dahulu dan mesti diadakan selepas panen tiba. Jika ada orang yang diputuskan akan mendapatkan gelar adat namun belum masuk masa tuai padi, upacara penobatan belum dapat dilakukan. Apabila masa panen/tuai padi tiba, tetapi tidak ada orang yang akan dinobatkan gelar adat, yang bisa dilaksanakan adalah kenduri sudah tuai. Selain itu, pemberian gelar adat mestilah berasal dari kaum yang menjadi keturunan pusaka gelar dan pusaka tanah kaum dari leluhurnya, bukan dari pihak luar kaum. Adapun filosofi masyarakat Kerinci yang terdapat di dalam tradisi KS adalah 1) filosofi keagamaan yang mewujud dalam bentuk ungkapan syukur dan terima kasih kepada Tuhan karena telah memberikan hasil panen sebagai sko dalam pemenuhan kebutuhan pokok kehidupan masyarakat Kerinci. Filosofi ini adalah hal baik yang harus dilakukan karena dipercaya akan diberikan berkah panen yang lebih berlimpah. 2) Filosofi kemanusiaan terimplementasi dalam ucapan syukur kepada Tuhan dan kepada leluhur yang telah memberikan sko ico pakai yang berupa tanah dan gelar adat, serta bagaimana nilai-nilai kemanusiaan itu dipraktikkan seperti menghargai, mengasihi orang lain, bekerja sama, dan menolong orang lain. 3) Filosofi demokrasi dan musyawarah terimplementasi dalam pemberian gelar adat kepada seseorang dengan sistem kerapatan yang dimulai dari pihak keluarga, tengganai, hingga depati ninik mamak sebagai putusan akhir. 4) Filosofi sosial kemasyarakatan mewujud dalam bentuk penghargaan, penghormatan kepada Tuhan dan 
leluhur, tenggang rasa dan menghormati orang lain dalam musyawarah gelar adat, kerja sama, gotong royong, dan hidup rukun di dalam masyarakat.

Melihat hasil temuan dari penelitian ini tentang filosofi masyarakat Kerinci dalam KS, menjadi sangat penting kiranya tradisi ini terus dipelajari dan dijadikan bahan edukasi kepada masyarakat terutama generasi muda dalam membangun tatanan kehidupan sosial budaya yang dimiliki. Tradisi KS ini dapat menjadi representasi bagaimana kearifan lokal dengan nilainilai kebaikan yang ada di masyarakat tersebut dapat dilakukan.

Akan tetapi, tradisi ini selalu berpotensi akan hilang jika filosofi penghormatan akan Tuhan, leluhur, dan kemanusiaan yang telah memberikan pusaka yang bisa digarap terhadap kaum juga hilang. Kehidupan modern dengan berbagai cara pandangnya dapat membawa perubahan kehidupan masyarakat, seperti perubahan pada mata pencaharian. Bergesernya mata pencaharian masyarakat Kerinci dari bertani menjadi pengusaha, bekerja di pemerintahan, TNI/Polri, dan sebagainya menyebabkan tanah pusaka tidak lagi digarap, dialihfungsikan, dan bahkan dijual kepada pihak luar. Tentu saja KS masih bisa dilaksanakan, tetapi esensi tradisi selepas panen dan filosofi ucapan syukur kepada yang memberi warisan berupa pusaka tanah menjadi hilang.

\section{DAFTAR PUSTAKA}

Abas, Y. (1985). Meninjau hukum adat alam Kerinci. In Sungai Penuh: Andalas.

Arzam, A. (2016). Gelar adat di Kerinci ditinjau dari ilmu sosial. AlQisthu: Jurnal Kajian Ilmu-Ilmu Hukum, 14(1). https://doi.org/10.32694/01060
Creswell, J. W. (2002). Educational research: Planning, conducting, and evaluating quantitative and qualitative research (Intergovernmental panel on climate change, Ed.). Pearson Education, inc.

Djamaris, E. (1993). Nilai budaya dalam beberapa karya sastra Nusantara; Sastra saerah di Sumatra. In Jakarta: Pusat Pembinaan dan Pengembangan .... .

Faturahman, B. M. (2018). Aktualisasi nilai demokrasi dalam perekrutan dan penjaringan perangkat desa. JURNAL SOSIAL POLITIK, 4(1), 134.

Fitria, A. (2007). Tenggelamnya makna asli upacara adat kenduri sko di Kerinci, Jambi. Historisme, 23, 29-32.

Geertz, C. (1983). Abangan, santri, priyayi dalam masyarakat Jawa. Jakarta: Pustaka Jaya. 1992. In Tafsir Kebudayaan. Yogyakarta: Kanisius. Kanisius.

Hapsari, S. (2015). Telaah teoritis: internalisasi nilai-nilai demokrasi dalam budaya sekolah. SOSIODIDAKTIKA: Social Science Education ..., 2(2), 188.

Helida, A. (2016). Perhelatan kenduri sko sebagai sebuah pesan kebudayaan masyarakat Kerinci di taman nasional Kerinci Seblat. Masyarakat, Kebudayaan Dan Politik. https://doi.org/10.20473/ mkp.v29i12016.35-45

Inglehart, R. (2006). Budaya dan demokrasi" dalam kebangkitan peran budaya: Bagaimana nilainilai membentuk kemajuan manusia, editor: Lawrence E. In Harrison dan Samuel $P$. Huntington. Jakarta: LP3ES. LP3ES.

Koentjaraningrat, K. (2004). 
Kebudayaan, mentalitas dan pembangunan. Gramedia Pustaka Utama.

Mackey, A., \& Gass, S. M. (2015). Second language research: Methodology and design. Lawrence ErlbaumAssociates, Inc.

Morris, B. (1987). Anthropological studies of religion: An introductory Text. Cambridge University Press.

Pranata, L., \& Ikhsan, R. (2018). Ritual tari tauh dalam kenduri sko ( studi interpretivisme simbolik: masyarakat Desa Lolo Hilir ). Sejarah Dan Budaya, 12(1), 4959.

http://journal2.um.ac.id/index.ph p/sejarah-danbudaya/article/view/4119

Price, J. M. C. (2007). Democracy: A critical red ideal. Journal of Thought.

Ramadani, Y., \& Qommaneeci, A. (2018). Pengaruh pelaksanaan kenduri sko (pesta panen) terhadap perekonomian dan kepercayaan masyarakat Kerinci, Provinsi Jambi. Jurnal Antropologi: Isu-Isu Sosial Budaya, 1. https://doi.org/10.25077/jantro.v2 0.n1.p71-83.2018

Sepdwiko, D. (2016). Hadirnya musik gong perunggu dalam upacara adat kenduri sko pada masyarakat Kerinci Provinsi Jambi. JURNAL SITAKARA, 1 .

Sudarsi, E. T., Taula'bi', N., \& Girik Allo, M. D. (2019). Filosofi tallu lolona dalam Himne Passomba Tedong (etnografi kearifan lokal Toraja) [The Philosophy of Tallu Lolona in the Hymns of Passomba Tedong (Ethnography of Torajan Local Wisdom)]. SAWERIGADING. https://doi.org/10.26499/sawer.v2 $5 \mathrm{i} 2.666$

Sukayasa, S., \& Awuy, E. (2014). Pengintegrasian nilai-nilai kemanusiaan (human values) dalam pembelajaran tematik sekolah dasar. In Jurnal Kreatif Tadulako (p. 2). core.ac.uk.

Syaputra Z.E., D. (2019). Ritus dan manuskrip: Analisis korelasi naskah dengan kenduri Sko di Kerinci. Hadharah, 13(2), 79102.

Yohanis, Y. (2020). Pembinaan nilainilai adat Basandi Syarak, Syarak Basandi Kitabullah oleh Ninik Mamak terhadap anak kemenakan di Kenagarian Situjuah Gadang, Kec. Limo Nagari Kabupaten Lima Puluh Kota. Ensiklopedia of Journal, 2, 113.

Zakaria, I. (1984). Tambo sakti alam Kerinci. Departemen Pendidikan dan Kebudayaan. 